\title{
Redclaw crayfish (Cherax quadricarinatus): spatial distribution and dispersal pattern in Java, Indonesia
}

\author{
Surya Gentha Akmal $^{1,2, *}$, Agus Santoso ${ }^{3}$, Yonvitner ${ }^{2,4}$, Ernik Yuliana ${ }^{5}$ and Jiří Patoka ${ }^{1}$ \\ ${ }^{1}$ Department of Zoology and Fisheries, Faculty of Agrobiology, Food and Natural Resources, Czech University of Life Science Prague, \\ Kamýcká 129, 16500 Prague - Suchdol, Czech Republic \\ ${ }^{2}$ Centre for Coastal and Marine Resources Studies, The Institute for Research and Community Service, IPB University, Bogor 16680 , Indonesia \\ 3 Department of Statistic, Faculty of Science and Technology, Indonesia Open University, Pondok Cabe, South Tangerang 154 37, Indonesia \\ ${ }^{4}$ Department of Aquatic Resources Management, Faculty of Fisheries and Marine Sciences, IPB University, Jl. Agatis, Kampus IPB \\ Dramaga, Bogor 166 80, Indonesia \\ ${ }^{5}$ Department of Biology, Faculty of Science and Technology, Indonesia Open University, Pondok Cabe, South Tangerang 154 37, Indonesia
}

Received: 12 February 2021 / Accepted: 23 March 2021

\begin{abstract}
Cherax quadricarinatus is a parastacid crayfish native to parts of north-eastern Australia and southern New Guinea. It is a relatively large and highly fecund species in comparison with other crayfish of this genus. Since $C$. quadricarinatus was previously assessed as an invasive species in Indonesia, further monitoring of this species in this region was recommended. Detailed understanding of its spatial behaviour can be the basis for further research aimed at improved management. Field sampling was performed outside its native range in Java, Indonesia from 2019-2020, resulting in data useful for modelling the species' spatial distribution. The occurrence of the species was confirmed in 66 of 70 surveyed localities with 51 new records for Indonesia. Future investigations focused on the relationship between the spatial distribution and dispersal pattern of $C$. quadricarinatus and its interactions with native biota and entire ecosystems were recommended.
\end{abstract}

Keywords: Biogeography / freshwater / invasive species / non-native species / Parastacidae / Southeast Asia

Résumé - L'écrevisse à pinces rouges (Cherax quadricarinatus): Distribution spatiale et schéma de dispersion à Java, Indonésie. Cherax quadricarinatus est une écrevisse parastacide originaire de certaines parties du nord-est de l'Australie et du sud de la Nouvelle-Guinée. C'est une espèce relativement grande et très féconde par rapport aux autres écrevisses de ce genre. Comme C. quadricarinatus a été précédemment évaluée comme une espèce envahissante en Indonésie, il est recommandé de suivre la surveillance de cette espèce dans cette région. Une compréhension détaillée de son comportement spatial peut servir de base à de nouvelles recherches visant à améliorer la gestion. Un échantillonnage de terrain a été effectué en dehors de son aire de répartition d'origine à Java, en Indonésie, de 2019 à 2020, ce qui a permis d'obtenir des données utiles pour modéliser la distribution spatiale de l'espèce. La présence de l'espèce a été confirmée dans 66 des 70 localités étudiées, avec 51 nouveaux enregistrements pour l'Indonésie. Des enquêtes futures axées sur la relation entre la distribution spatiale et le modèle de dispersion de C. quadricarinatus et ses interactions avec le biote indigène et les écosystèmes entiers ont été recommandées.

Mots clés : Biogéographie / eau douce / espèces envahissantes / espèces non indigènes / Parastacidae / Asie du Sud-Est

\section{Introduction}

Invasive species cause environmental and socio-economic losses throughout the world (Pimentel, 2011). In Indonesia also, several invasive species are known to pose serious threats

\footnotetext{
${ }^{*}$ Corresponding author: akmal@af.czu.cz
}

to native biota and have profound impacts on the entire ecosystem via suppressed growth, non-native pathogen transmission, habitat alteration, competition, hybridization, and predation on native species (Torchin et al., 2003; Peeler and Taylor, 2011; Strauss et al., 2012).

The spread of invasive species has recently increased in aquatic ecosystems in Indonesia, both of vertebrates 
(Muchlisin, 2012; Marková et al., 2020; Patoka et al., 2020) and invertebrates (Marwoto et al., 2018; Putra et al., 2018). The increase in invasive species can sometimes be economically beneficial, but it is also necessary to consider and predict the impact of the introductions on aquatic ecosystems (Yonvitner et al., 2020). The existence of non-native species complicates the management of aquatic species stocks and biodiversity conservation in invaded waters also because the current legislative regulations are ineffective in many cases (Patoka et al., 2018a).

Introductions of non-native species are commonly perceived from both intercontinental and international perspectives but especially in island countries, the regional scale may be important (Lenzner et al., 2020). Redclaw crayfish Cherax quadricarinatus (Decapoda: Astacidea: Parastacidae) is a known successful invasive species especially in tropical regions across the world (Haubrock et al., 2021 and citations herein) and it has spread also within the Indonesian territory out of its native range (Patoka et al., 2018b). This species is native to north-eastern Australia and southern New Guinea. Although the western part of New Guinea belongs to Indonesian territory, the species has to be perceived intranationally as non-native in the rest of the country (Bláha et al., 2016). The purpose of new introductions of C. quadricarinatus is usually related to its economic value for human consumption and ornamental trade (Negara, 2012; Haubrock et al., 2021). Both purposes were previously recorded also in Indonesia (Patoka et al., 2018b).

In comparison with other members of this genus (Weiperth et al., 2020), C. quadricarinatus is highly adaptable to various water quality parameters such as different levels of oxygen, ammonia, hardness, alkalinity, and $\mathrm{pH}$ (Rouse et al., 1991). This crayfish is able to live in waters with water temperatures ranging from 10 to $31{ }^{\circ} \mathrm{C}$ (Haubrock et al., 2021).

Since Indonesia has been identified as the leading exporter of ornamental crayfish globally (Patoka et al., 2015), and C. quadricarinatus is one of the most popular pet-traded species (Kotovska et al., 2016; Vodovsky et al., 2017), the further intentional spread of this species in the country is expected. Another invasive and also popular ornamental crayfish found established in Indonesia, the North American red swamp crayfish Procambarus clarkii, is classified as being much more harmful than C. quadricarinatus. Nevertheless, the latter is also perceived as a risky species potentially negatively impacting the native Indonesian biota (Patoka et al., 2016; Putra et al., 2018).

Mitigation efforts need to be based on investigating the distribution of invasive species in the landscape (Glen et al., 2013; Padalia et al., 2014). These efforts form the basis for the preparation of mitigation and eradication plans, knowing distribution patterns, and protection of native species biodiversity from non-native threats (Molnar et al., 2008). Research related to the spatial distribution and dispersal patterns of invasive species in Indonesia in general and of invasive crayfish in particular has not been widely carried out. Since crayfish are transported across the majority of Java via various routes and in huge quantities, we have updated the data about the distribution of $C$. quadricarinatus in this Indonesian island.

\section{Materials and methods}

\subsection{Study area}

The research was conducted in freshwaters on the island of Java, Indonesia, by field surveys. The selection of locations was carried out after considering the local aquatic conditions, with a special focus on streams, lakes, and reservoirs. In total, 70 locations (47 natural lakes and streams, 23 artificial ponds and reservoirs) were selected and sampled. Crayfish were collected from each of the surveyed locations when they occurred there. In the initial stage, the current status of the recorded populations was evaluated and their spatial distribution was determined.

\subsection{Data collection}

Data were collected during the whole season between August 2019 and August 2020. Crayfish were captured during a one-night sampling session at each selected locality using bamboo and/or foldable net traps baited with fish and gastropod meat. The types of data collected were biological, ecological, socio-economic and community data. Temporal information was also needed as a follow-up step from the results of spatial analysis in different periods to obtain dynamic patterns of spatial change. For each site, all collected crayfish specimens were preserved in $70 \%$ ethanol for later laboratory identification. Relative abundance was recorded for each locality. All voucher specimens were deposited in the Fisheries Biology Laboratory, Department of Aquatic Resources Management, Faculty of Fisheries and Marine Science, IPB University in Bogor, Indonesia. The species was identified based on morphological characteristics suggested by von Martens (1868), Holthius (1949), Souty-Grosset et al. (2006), and Haubrock et al. (2021).

\subsection{Data analysis}

Data processing software used was QGIS Standalone version 3.16.0-Hannover (64 bit). Several aspects need to be considered in making a database design, including (a) describing the object; (b) analyzing the available data; (c) physical design; (d) linking spatial data with the database; and (e) implementation. Results of the distribution survey and statistical analysis were compared with range-wide distribution records of the species to determine possible relationships among distributions. The morphological parameter measurements included: ocular carapace length, chela length, propodal membrane length, dactyl length, chela width, cephalon width, thorax width, carapace depth, total carapace length, abdominal length, telson length, telson width, abdominal width, uropod length, cheliped (1st pereiopod) length, 2nd-5th pereiopod lengths, weight, and rostral spine count. Morphological parameter measurements were used for strain comparison. All linear measurements were made with vernier calipers (accuracy $0.1 \mathrm{~mm}$ ) to nearest $\mathrm{mm}$. Weight was measured on an Adam CB-1001 1,000 g/0.01 g digital electronic weight scale to nearest gram. Abnormal deformations such as bifid or curved rostrum (Yuliana et al., 2019) and regenerated claws were excluded from the morphological analysis. The Kruskal Wallis method was used to determine significant morphometric 


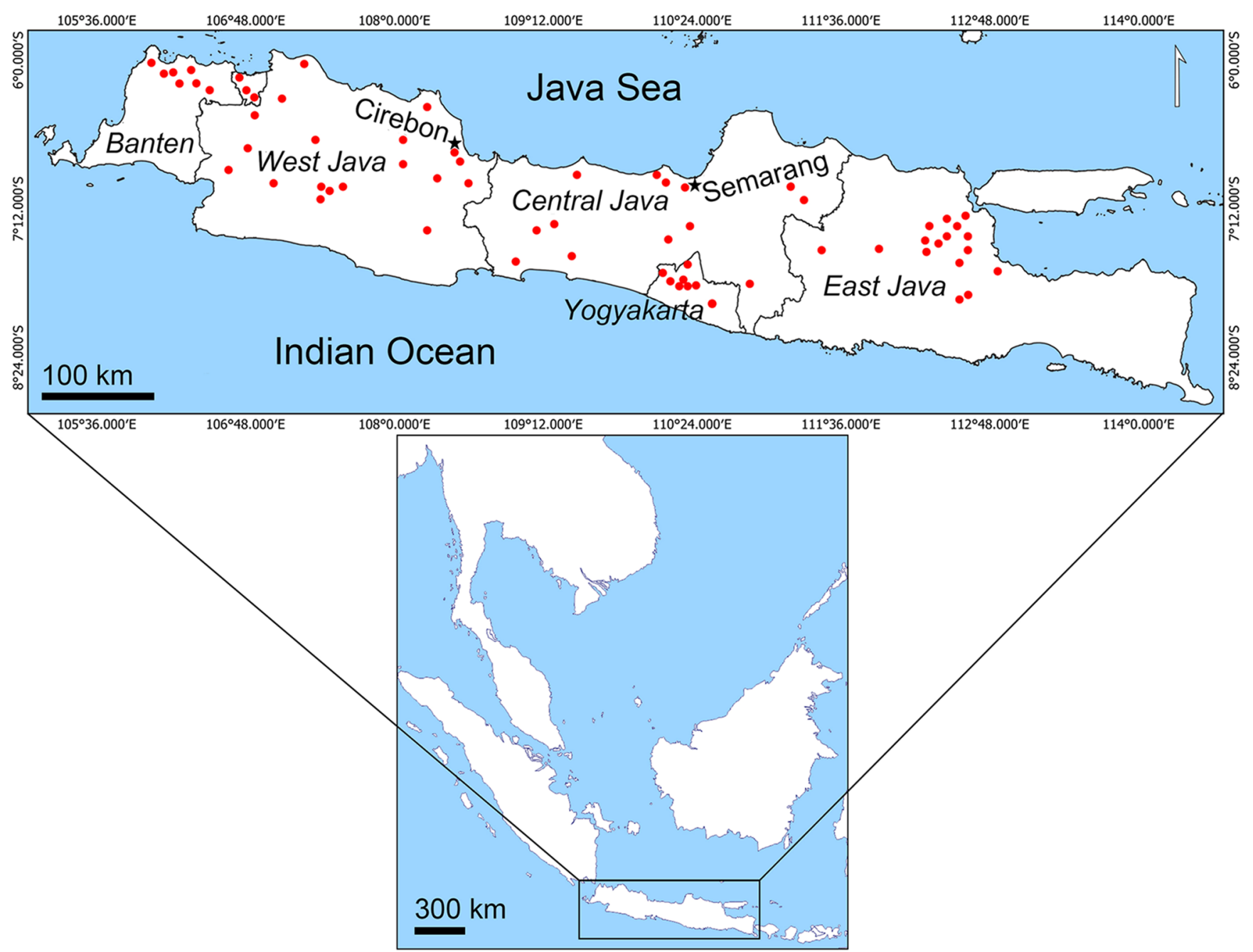

Fig. 1. The current distribution of Cherax quadricarinatus in Java island. The red dots indicate the established populations. Name of provinces are italicized while source regions are indicated by an asterisk, except for Yogyakarta which is the name of the province and also of a source region.

differences between the $C$. quadricarinatus groups at their source regions. Discriminant analysis was used to determine population groupings based on different locations. The software used for discriminant analysis was the IBM SPSS Statistics for Windows, Version 23.0. Armonk.

\section{Results}

Cherax quadricarinatus was found to occur at 66 of 70 sampled locations (43 natural and 23 artificial, Tab. S1). Its scattered distribution in several regions on Java island is presented in Figure 1. A reproducing population was found in each locality where C. quadricarinatus occurred. Most of them were being cultured in ponds and tanks for ornamental purposes and some of them also for human consumption. All populations found in the wild originated from one of the three following source regions: Cirebon, Semarang, and Yogyakarta (Tab. 1). The total body length range was $52.88-139.77 \mathrm{~mm}$ $($ mean $=103.06 \mathrm{~mm} ; \mathrm{N}=17$ ) in Cirebon, $69.74-177.58 \mathrm{~mm}$
Table 1. Results of global positioning system measurements of wild Cherax quadricarinatus populations in three Javanese source regions: Cirebon, Semarang, and Yogyakarta.

\begin{tabular}{llll}
\hline Region & \multicolumn{2}{c}{ GPS } & Habitat type \\
\cline { 2 - 3 } & Latitude & Longitude & \\
\hline Cirebon & -6.879271 & 108.578073 & Lake \\
Cirebon & -6.784961 & 108.567211 & Lake \\
Cirebon & -6.734638 & 108.564482 & River \\
Semarang & -7.285690 & 110.435825 & Lake \\
Semarang & -7.254928 & 110.458398 & River \\
Yogyakarta & -7.786604 & 110.381592 & Reservoir \\
Yogyakarta & -7.754888 & 110.413565 & Reservoir \\
Yogyakarta & -7.788148 & 110.296371 & Reservoir \\
Yogyakarta & -7.749287 & 110.489223 & River \\
Yogyakarta & -7.824455 & 110.123569 & Reservoir \\
\hline
\end{tabular}


Table 2. The significantly different morphological characters of Cherax quadricarinatus populations in Java.

\begin{tabular}{|c|c|c|c|c|c|}
\hline \multirow{2}{*}{$\begin{array}{l}\text { Morphological parameter } \\
\text { (length = mm; weight }=\mathrm{g} \text { ) }\end{array}$} & \multicolumn{5}{|c|}{ Average ratio } \\
\hline & Cirebon & Semarang & Yogyakarta & df & $p$-Value \\
\hline Ocular carapace length & $0.7615 \pm 0.0253$ & $0.8120 \pm 0.0292$ & $0.7966 \pm 0.0587$ & 2 & 0.0030 \\
\hline Dactyl length & $0.3156 \pm 0.0333$ & $1.0031 \pm 0.2112$ & $0.3220 \pm 0.0349$ & 2 & $<0.0001$ \\
\hline Chela length & $0.2135 \pm 0.0580$ & $0.8867 \pm 0.2749$ & $0.1937 \pm 0.0388$ & 2 & $<0.0001$ \\
\hline Cephalon width & $0.3697 \pm 0.0103$ & $0.9255 \pm 0.1163$ & $0.3929 \pm 0.0172$ & 2 & $<0.0001$ \\
\hline Thorax width & $0.4360 \pm 0.0166$ & $1.2035 \pm 0.2154$ & $0.4457 \pm 0.0237$ & 2 & $<0.0001$ \\
\hline Telson length & $0.3197 \pm 0.0213$ & $0.3282 \pm 0.0188$ & $0.3381 \pm 0.0186$ & 2 & 0.0030 \\
\hline Telson width & $0.2471 \pm 0.0185$ & $0.2430 \pm 0.0124$ & $0.2227 \pm 0.0222$ & 2 & $<0.0001$ \\
\hline Uropod length & $0.3828 \pm 0.0278$ & $0.3933 \pm 0.0202$ & $0.4083 \pm 0.0296$ & 2 & $<0.0001$ \\
\hline 2nd pereiopod length & $0.8185 \pm 0.0622$ & $0.8410 \pm 0.0672$ & $0.7962 \pm 0.0443$ & 2 & 0.0040 \\
\hline 3rd pereiopod length & $1.0240 \pm 0.0881$ & $1.0583 \pm 0.0671$ & $0.9994 \pm 0.0647$ & 2 & 0.0010 \\
\hline 4th pereiopod length & $0.9171 \pm 0.0449$ & $0.9511 \pm 0.0668$ & $0.9051 \pm 0.0461$ & 2 & 0.0010 \\
\hline 5th pereiopod length & $0.8233 \pm 0.0583$ & $0.8587 \pm 0.0648$ & $0.8154 \pm 0.0519$ & 2 & 0.0020 \\
\hline
\end{tabular}

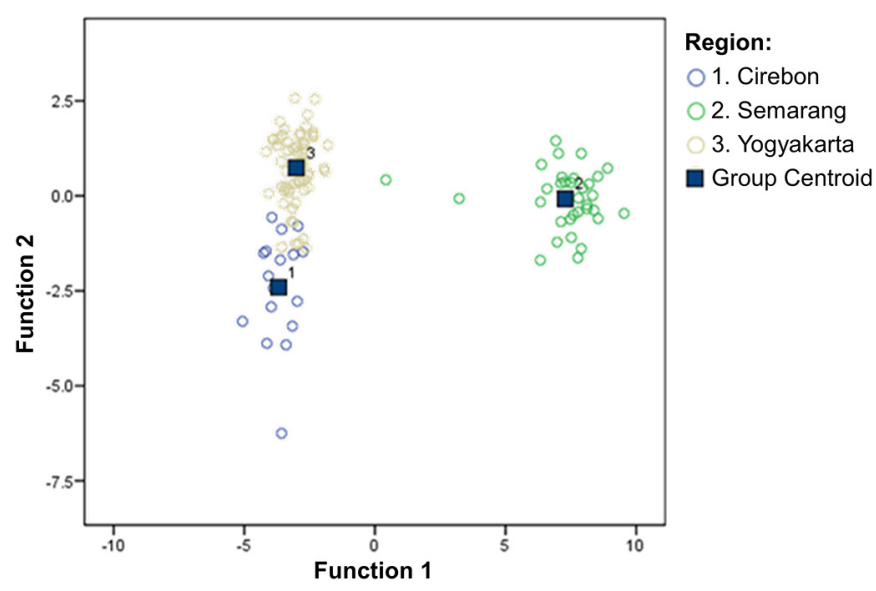

Fig. 2. Discriminant result grouping of Cherax quadricarinatus on standard morphological measures. The discriminant analysis serves to show clear groupings characterized by differences in the centroid position. The analysis showed significant differences among groups in Cirebon (1), Semarang (2), and Yogyakarta (3).

(mean $=110.38 \mathrm{~mm} ; \mathrm{N}=33)$ in Semarang, and 66.97-144.6 $\mathrm{mm}$ (mean $=89.23 \mathrm{~mm} ; \mathrm{N}=59)$ in Yogyakarta. Cherax quadricarinatus locality tracing was based on pathways in Java. We found the $C$. quadricarinatus being commonly traded as a popular ornamental creature in Java.

Based on the discriminant function in statistical analysis, the results of grouping $C$. quadricarinatus on standard measurements indicated three groups marked by differences in the centroid location (Fig. 2). Individuals in each population from mainland waters in Cirebon, Semarang and Yogyakarta were grouped appropriately at $88.24 \%, 96.97 \%$, and $91.53 \%$ respectively. Discriminant analysis was carried out to see the closeness of the correlation based on the similarity of certain crayfish body sizes. Morphometric characters that had the same values indicated a mix of measured populations from one population to another. Discriminant analysis from standard morphometric methods showed that the populations of C. quadricarinatus in the three localities differed significantly. Significantly different morphological characters were the following: chela length, cephalon width, dactyl length, ocular carapace length, telson length, telson width, thorax length, uropod length, 2nd pereiopod length, 3nd pereiopod length, 4rd pereiopod length and 5th pereiopod length (Tab. 2).

\section{Discussion}

In total, we found $C$. quadricarinatus to be wellestablished in 66 localities in Java, Indonesia, with 51 new records of the species on this island in addition to previous records reported by Patoka et al. (2018b). As suggested previously, climatic conditions in Java are suitable for its establishment (Patoka et al., 2016) and the largest populations were found in Cirebon, Semarang, and Yogyakarta. The encounter points are in line with the pathways of ornamental and thus $C$. quadricarinatus can probably inhabit many different streams, reservoirs, lakes, and other inland freshwater bodies in Java.

Discriminant analysis showed that populations of C. quadricarinatus found in Cirebon, Semarang, and Yogyakarta are significantly different. Different environmental conditions lead to adaptations that are marked by differences in morphological characters (Webster, 2007). Variations in morphological characters occur as an adaptation response to environmental conditions (Patoka et al., 2017). Such variation could be caused by differences related to altitude (Cirebon: from 0 to 300 masl; Semarang: from 0 to 1500 masl; Yogyakarta: from 0 to 450 masl) or to local environmental conditions (Snovsky and Galil, 2011; Fahri et al., 2013; Darmansyah et al., 2014; Vitasurya, 2016).

The occurrence of a non-indigenous crayfish population in any ecosystem worldwide needs to be managed properly so that it can be utilized optimally and appropriately and does not negatively interfere with other crustaceans and native species in general. This point is crucial and is often not easy to follow 
up in many species and many regions. Cherax quadricarinatus has a high environmental tolerance, is easy to sell alive and ship worldwide, demand is relatively high and the market is wide open (Wu et al., 2018; Ghanawi et al., 2019; Lin et al., 2020). This crayfish is very popular in the aquaculture industry because it has good resistance, adaptability to various food types, and is fast growing (Vodovsky et al., 2017). Indonesia is one of the countries that have carried out a lot of C. quadricarinatus cultivation. This species is cultivated there both in natural and artificial waters such as lakes, reservoirs, ponds, indoor tanks and aquaria, and traded both locally and exported abroad (Patoka et al., 2018b).

Given both the positive and negative aspects related to C. quadricarinatus culture in Indonesia, it is necessary to educate the general public. Control measures that can be taken to reduce or mitigate the unwanted feral populations of C. quadricarinatus released into public waters can be implemented through economic uses, such as consumption and sales. However, when management is carried out the most important thing is to avoid release of the captured crayfish elsewhere (Patoka et al., 2018a). This must be a major concern because these freshwater crayfish also jeopardize the environment. For example, by reducing biomass of aquatic plants, crayfish reduce the availability of shelters for macroinvertebrates and fishes (James et al., 2015). Cherax quadricarinatus can also negatively affect native species, through direct competition, predation, or habitat modification, and may host parasites previously absent in native populations (Haubrock et al., 2021). For instance, various species of bacteria are known to infect C. quadricarinatus (Hayakijkosol et al., 2017).

In line with previous records (Patoka et al., 2016, 2018b), it is obvious that spread of $C$. quadricarinatus is increasing at least in Java. Regarding related risks in Indonesia, C. quadricarinatus should be cultured strictly in isolated systems. Feral populations of this crayfish can be also controlled through increasing the exploitation rate for human consumption. On the other hand, the increasing demand can cause an unwanted future spread of $C$. quadricarinatus in the region, and hence the directed education of the general public is crucial in this regard. Future investigations focused on relationships between the spatial distribution and dispersal pattern of C. quadricarinatus and its interactions with native biota and entire ecosystems are recommended. Also, the further detailed monitoring of introduced species including crayfish in Indonesian waters is strongly recommended.

\section{Supplementary Material}

Table S1. The full record list of Cherax quadricarinatus populations recorded in Java, Indonesia: name of the region, GPS, type of the habitat: natural (lakes, streams) or artificial (ponds, reservoirs).

The Supplementary Material is available at https://www.kmaejournal.org/10.1051/kmae $/ 2021015 / \mathrm{olm}$.

Acknowledgments. Thanks to colleagues and students who helped us with the survey, namely: Rafialwan Athariq Subing and Sultan Al Riza Ritonga, Fish Quarantine and Inspection Agency, and the local farmers. This study was funded by DIPA Indonesia Open University T.A. 2020 No. SP DIPA-023.17.2.677531. The cooperation was supported by
The Indonesian Crayfish Research Group. English was proofread by Julian D. Reynolds.

\section{References}

Bláha M, Patoka J, Kozák P, Kouba A. 2016. Unrecognized diversity in New Guinean crayfish species (Decapoda, Parastacidae): the evidence from molecular data. Integr Zool 11: 457-468.

Darmansyah A, Rochana SH, Sutardi A, Zuraida U. 2014. The new growth centres and strategy for building and accelerating agribusiness development in Cirebon Regency, Indonesia. Procedia Soc Behav Sci 115: 296-304.

Fahri S, Yohan B, Trimarsanto H, Sayono S, Hadisaputro S, Dharmana E, Syafruddin D, Sasmono RT. 2013. Molecular surveillance of dengue in Semarang, Indonesia revealed the circulation of an old genotype of dengue virus serotype-1. PLoS Negl Trop Dis 7: e2354.

Ghanawi J, Saoud G, Zakher C, Monzer S, Saoud IP. 2019. Clove oil as an anaesthetic for Australian redclaw crayfish Cherax quadricarinatus. Aquac Res 50: 3628-3632.

Glen AS, Pech RP, Byrom AE. 2013. Connectivity and invasive species management: towards an integrated landscape approach. Biol Invasions 15: 2127-2138.

Haubrock PJ, Oficialdegui FJ, Zeng Y, Patoka J, Yeo DCJ, Kouba A. 2021. The redclaw crayfish: a prominent aquaculture species with invasive potential in tropical and subtropical biodiversity hotspots. Rev Aquac. https://doi.org/10.1111/raq.12531

Hayakijkosol O, Owens L, Picard J. 2017. Case report of bacterial infections in a redclaw crayfish (Cherax quadricarinatus) hatchery. Aquaculture 475: 1-7.

Holthius LB. 1949. Decapoda Macrura, with a revision of the New Guinea Parastacidae. Zoological Results of the Dutch New Guinea Expedition 1939, No. 3. Nova Guinea 5, Tallahassee(US), pp. 289-328.

James J, Slater FM, Vaughan IP, Young KA, Cable J. 2015. Comparing the ecological impacts of native and invasive crayfish: could native species' translocation do more harm than good? Oecologia 178: 309-316.

Kotovska G, Khrystenko D, Patoka J, Kouba A. 2016. East European crayfish stocks at risk: arrival of non-indigenous crayfish species. Knowl Manag Aquat Ecosyst 417: 37.

Lenzner B, Latombe G, Capinha C, Bellard C, Courchamp F, Diagne C, Dullinger S, Golivets M, Irl S, Kühn I, Leung B, Liu C, Moser D, Roura-Pascual N, Seebens H, Turbelin A, Weigelt P, Essl F. 2020. What will the future bring for biological invasions on islands? An expert-based assessment. Front Ecol Evol 8: 280.

Lin W, Guo G, Zou C, Shi H, Ruan L. 2020. Large-scale screening of molecules involved in virus-host interaction by specific compounds in Cherax quadricarinatus hematopoietic tissue cells. Aquaculture 527: 735435.

Marková J, Jerikho R, Wardiatno Y, Kamal MM, Magalhães ALB, Bohatá L, Kalous L, Patoka J. 2020. Conservation paradox of giant arapaima Arapaima gigas (Schinz, 1822) (Pisces: Arapaimidae): endangered in its native range in Brazil and invasive in Indonesia. Knowl Manag Aquat Ecosyst 421: 47.

Marwoto RM, Isnaningsih NR, Joshi RC. 2018. The invasive apple snail (Pomacea spp.) in Indonesia. Agric Dev 35: 41-48.

Molnar JL, Gamboa RL, Revenga C, Spalding MD. 2008. Assessing the global threat of invasive species to marine biodiversity. Front Ecol Environ 6: 485-492.

Muchlisin ZA. 2012. First report on introduced freshwater fishes in the waters of Aceh, Indonesia. Fish Aquat Life 20: 129-135.

Negara FK. 2012. Budidaya Losbter Air Tawar, Persepktive Bisnis, Amikom Yogyakarta, Yogyakarta. 
Padalia H, Srivastava V, Kushwaha SPS. 2014. Modeling potential invasion range of alien invasive species, Hyptis suaveolens (L.) Poit. in India: Comparison of MaxEnt and GARP. Ecol Inform 22: 36-43.

Patoka J, Kalous L, Kopecký O. 2015. Imports of ornamental crayfish: the first decade from the Czech Republic's perspective. Knowl Manag Aquat Ecosyst 416: 04.

Patoka J, Wardiatno Y, Yonvitner, Kuř́iková P, Petrtýl M, Kalous L. 2016. Cherax quadricarinatus (von Martens) has invaded Indonesian territory west of the Wallace Line: evidences from Java. Knowl Manag Aquat Ecosyst 417: 39.

Patoka J, Bláha M, Kouba A. 2017. Cherax acherontis (Decapoda: Parastacidae), the first cave crayfish from the Southern Hemisphere (Papua Province, Indonesia). Zootaxa 4363: 137-144.

Patoka J, Magalhães ALB, Kouba A, Faulkes Z, Jerikho R, Vitule JRS. 2018a. Invasive aquatic pets: failed policies increase risks of harmful invasions. Biodivers Conserv 27: 3037-3046.

Patoka J, Wardiatno Y, Mashar A, Yonvitner, Wowor D, Jerikho R, Takdir M, Purnamasari L, Petrtýl M, Kalous L, Kouba A, Bláha M. 2018b. Redclaw crayfish, Cherax quadricarinatus (von Martens, 1868), widespread throughout Indonesia. BioInvasions Rec 7: 185-189.

Patoka J, Takdir M, Yonvitner, Aryadi H, Jerikho R, Nilawati J, Tantu FY, Bohatá L, Aulia A, Kamal MM, Wardiatno Y, Petrtýl M. 2020. Two species of illegal South American sailfin catfish of the genus Pterygoplichthys well-established in Indonesia. Knowl Manag Aquat Ecosyst 421: 28.

Peeler EJ, Taylor NG. 2011. The application of epidemiology in aquatic animal health - opportunities and challenges. Vet Res 42: 1-15.

Pimentel D. 2011. Biological invasions. economic and environmental costs of alien plant, animal, and microbe species. Florida: CRC Press, p. 449.

Putra MD, Bláha M, Wardiatno Y, Krisanti M, Yonvitner, Jerikho R, Kamal MM, Mojžišová M, Bystřický PK, Kouba A, Kalous L, Petrusek A, Patoka J. 2018. Procambarus clarkii (Girard, 1852) and crayfish plague as new threats for biodiversity in Indonesia. Aquat Conserv 28: 1434-1440.

Rouse DB, Austin CM, Medley PB. 1991. Progress toward profits? information on the Australian crayfish. Aquac Mag 17: 46-56.

Snovsky G, Galil B. 2011. The australian redclaw crayfish Cherax quadricarinatus (Von Martens, 1868) (Crustacea: Decapoda:
Parastactidae) in the Sea of Galilee, Israel. Aquat Invasions 6: 29-31.

Souty-Grosset C, Holdich DM, Noel PY, Reynolds JD, Haffner P. 2006. Atlas of crayfish in Europe. Paris, France: Muséum National d'Histoire Naturelle. p. 187.

Strauss A, White A, Boots M. 2012. Invading with biological weapons: the importance of disease-mediated invasions. Funct Ecol 26: 1249-1261.

Torchin ME, Lafferty KD, Dobson AP, McKenzie VJ, Kuris AM. 2003. Introduced species and their missing parasites. Nature 421: $628-630$.

Vitasurya VR. 2016. Local wisdom for sustainable development of rural tourism, case on kalibiru and Lopati village, Province of Daerah Istimewa Yogyakarta. Procedia Soc Behav Sci 216: 97-108.

Vodovsky N, Patoka J, Kouba A. 2017. Ecosystem of Caspian Sea threatened by pet-traded non-indigenous crayfish. BioInvasions Rec 19: 2207-2217.

von Martens E. 1868. Über eine neue Art und Untergattung der Cyprinoiden, Homaloptera (Octonema) rotundicauda, über einige neue Crustaceen und über die neuholländischen Süsswasserkrebse. Monatsberichte der Königlichen Akademie der Wissenschaften zu Berlin. Physikalisch-mathematische Klasse, Berlin, pp. 607-619.

Webster M. 2007. A Cambrian peak in morphological variation within trilobite species. Science 5837: 499-502.

Weiperth A, Bláha M, Szajbert B, Seprős R, Bányai Z, Patoka J, Kouba A. 2020. Hungary: a European hotspot of non-native crayfish biodiversity. Knowl Manag Aquat Ecosyst 421: 43.

Wu D-L, Liu Z-Q, Huang Y-H, Lv W-W, Chen M-H, Li Y-M, Zhao Y-L. 2018. Effects of cold acclimation on the survival, feeding rate, and non-specific immune responses of the freshwater red claw crayfish (Cherax quadricarinatus). Aquac Int 26: 557-567.

Yonvitner, Patoka J, Yuliana E, Bohatá L, Tricarico E, Karella T, Kouba A, Reynolds JD. 2020. Enigmatic hotspot of crayfish diversity at risk: Invasive potential of non-indigenous crayfish if introduced to New Guinea. Aquat Conserv 30: 219-224.

Yuliana E, Yonvitner, Bláha M, Patoka J. 2019. Unusual rostral deformity in Cherax quadricarinatus (von Martens, 1868). Workshop on Biodiversity, Jevany, Czech Republic 11: 201-206.

Cite this article as: Akmal SG, Santoso A, Yonvitner, Yuliana E, Patoka J. 2021. Redclaw crayfish (Cherax quadricarinatus): spatial distribution and dispersal pattern in Java, Indonesia. Knowl. Manag. Aquat. Ecosyst., 422, 16. 